\title{
Analiza przyczyn przyjęć dzieci na Szpitalny Oddział Ratunkowy w Stupsku
}

\section{An analysis of the causes of the admission of children to the Emergency Department in Stupsk}

\author{
Sylwia Jałtuszewska ${ }^{\boxplus}$, Kazimiera Hebel ${ }^{1}$, Elżbieta Grygorowicz'1 ${ }^{1}$ Wiesław Kowalewski² \\ ${ }^{1}$ Akademia Pomorska w Słupsku, Instytut Nauk o Zdrowiu, ul. Bohaterów Westerplatte 64, 76-200 Słupsk \\ ${ }^{2}$ Państwowa Wyższa Szkoła Zawodowa w Koszalinie, Instytut Nauk Humanistycznych, ul. Leśna 1, 75-582 Koszalin \\ $\bowtie$ sjaltuszewska@wp.pl
}

\begin{abstract}
Introduction: Childhood illnesses are a major problem that very often require the emergency hospitalization of children. In 2013 the largest percentage of hospitalized children were those up to 4 years old. The most common cause of hospitalization for children is respiratory infections of viral, bacterial and allergic origin. The conducted research aimed at analyzing the most common causes of admissions of children to the Emergency Department in Słupsk (ED).

Materials and methods: The research group represented 372 paediatric patients aged up to 4 years who were admitted to the ED in 2013.

Results: The examined group comprised 372 (100\%) children. The average age was $23.20( \pm 16.06)$ months. The largest group
\end{abstract}

comprised children transferred to hospital - 217 (58.33\%) patients, of whom $50 \%$ were children referred to the Paediatric Department. The most common cause of admission was respiratory diseases, representing nearly $30 \%$ of all cases. The analysis of the relationship between the groups, and the cause of admission to the ED revealed a statistical significance between the variables $(p=0.0021)$. Most admissions were between the hours 12.00-23.59.

Conclusions: The most common cause for the admission of children to the ED was respiratory diseases. There were more children transferred to another hospital ward than discharged for outpatient treatment.

Keywords: child; Emergency Department; causes of admission.

\begin{abstract}
ABSTRAKT
Wstęp: Choroby wieku dziecięcego to obecnie istotny problem, który zdecydowanie często wymaga nagłej hospitalizacji. W 2013 r. największy odsetek objętych leczeniem szpitalnym obejmował dzieci do 4. r.ż. Najczęstszą przyczyną hospitalizacji są zakażenia układu oddechowego o podłożu wirusowym, bakteryjnym i alergicznym, gorączka oraz urazy.

Celem pracy była identyfikacja przyczyn przyjęć dzieci na Szpitalny Oddział Ratunkowy w Słupsku (SOR) oraz ustalenie, od jakich zmiennych zależało przyjęcie na inny oddział szpitalny bądź wypisanie dziecka z SOR.

Materiały i metody: Grupę badawczą stanowiło 372 pacjentów pediatrycznych w wieku do 4 lat przyjętych na SOR Wojewódzkiego Szpitala Specjalistycznego w Słupsku w 2013 r. Dane zebrano ze szpitalnego elektronicznego systemu ESKULAP.
\end{abstract}

Wyniki: W badanej grupie było 372 (100\%) dzieci. Średnia wieku wynosiła 23,20 $( \pm 16,06)$ miesięcy. Najliczniejszą grupę stanowiły dzieci przekazane do leczenia szpitalnego - 217 (58,33\%), z czego $50 \%$ skierowano na Oddział Pediatryczny. Najczęstszą przyczyną przyjęć były choroby układu oddechowego stanowiące blisko $30 \%$ wszystkich przypadków. Na podstawie analizy zależności pomiędzy grupami a przyczyną przyjęcia na SOR wykazano istotność statystyczną pomiędzy zmiennymi ( $p=0,0021)$. Najwięcej przyjęć było w godz. 12.00-23.59.

Wnioski: Najczęstszą przyczyną przyjęć dzieci na SOR były choroby układu oddechowego. Dzieci przekazanych na inny oddział szpitalny było więcej niż wypisanych do leczenia ambulatoryjnego.

Słowa kluczowe: dziecko; Szpitalny Oddział Ratunkowy; przyczyna przyjęcia; wypisanie.

\section{WSTĘP}

Chory pediatryczny jest specyficznym pacjentem, wymagającym od personelu medycznego wiedzy i szczególnych umiejętności obserwacji, analizy objawów oraz ogromnej empatii. Zachorowania mogące stanowić przyczynę zagrożenia zdrowia lub życia i wypadki z udziałem dzieci wymagające nagłej interwencji medycznej zdarzają się niemal codziennie, a miejscem pierwszego kontaktu w takich sytuacjach jest Szpitalny Oddział Ratunkowy (SOR). Według danych statystycznych

z 2013 r., opracowanych przez UNICEF w Polsce, największy odsetek dzieci objętych leczeniem szpitalnym dotyczył tych do 4. r.ż. - 15,6\% [1]. Najczęstszą przyczyną hospitalizacji dzieci były zakażenia układu oddechowego o podłożu wirusowym, bakteryjnym i alergicznym. W grupie wiekowej do 3. r.ż. ok. 95\% dzieci przynajmniej raz przebyło chorobę infekcyjną dróg oddechowych. Wśród niemowląt i młodszych dzieci częstą przyczyną hospitalizacji była gorączka oraz urazy, które nieodłącznie wiążą się z rozwojem dziecka [2]. Świadomość różnic i odmienności w postępowaniu terapeutycznym 
i pielęgnacyjnym z pacjentem pediatrycznym wyzwala wśród personelu medycznego stres i niepokój. Dlatego też analizowanie przyczyn przyjęć dzieci oraz znajomość schorzeń najczęściej występujących u pacjenta pediatrycznego przyjmowanego w strukturach państwowego ratownictwa medycznego wymaga od personelu ciągłego poszerzania zarówno wiedzy teoretycznej, jak i umiejętności praktycznych. Zespół terapeutyczny świadomy konieczności ciągłego dokształcania, kierujący się dobrem małego pacjenta, z poświęceniem i pasją wykonujący swoje zawodowe obowiązki nie będzie miał poczucia niepewności i wyzwania w postępowaniu z dzieckiem.

Celem pracy była identyfikacja przyczyn przyjęć dzieci na SOR oraz ustalenie, jakie zmienne warunkowały przyjęcie na inny oddział szpitalny lub wypisanie dziecka z SOR.

\section{MATERIAŁY I METODY}

Grupę badawczą stanowiło 372 pacjentów pediatrycznych w wieku do 4 lat, którzy zostali przyjęci na Szpitalny Oddział Ratunkowy Wojewódzkiego Szpitala Specjalistycznego w Słupsku w 2013 r. Pacjenci byli transportowani przez Zespół Ratownictwa Medycznego lub przybyli z opiekunem prawnym. Dane zebrano ze szpitalnego elektronicznego systemu ESKULAP. Pozyskane zmienne dotyczyły: płci, wieku, miejsca zamieszkania, daty przyjęcia na SOR, przyczyny przybycia na SOR, godziny przyjęcia i wypisu z SOR lub przekazania dziecka na inny oddział szpitalny oraz wieku matki i ojca dziecka. Dane zgromadzono w postaci bazy danych, następnie wprowadzono je do arkusza kalkulacyjnego MS Excel 2010. Analizę statystyczną przeprowadzono za pomocą pakietu statystycznego Statistica PL v. 9.1. Obliczono średnią arytmetyczną oraz odchylenie standardowe ( \pm ). Rozkład każdej zmiennej ilościowej zobrazowano przy wykorzystaniu wykresu normalności, gdzie - zgodnie z twierdzeniem Fishera - w miarę wzrostu liczności próby, rozkład statystyki testowej zbliża się do rozkładu normalnego, nawet wówczas, gdy mierzona zmienna nie posiada rozkładu normalnego [3]. Zależność pomiędzy zmiennymi określono, wykorzystując macierz korelacji, gdzie dla zmiennych jakościowych porządkowych i nominalnych użyto testu ANOVA analiza wariancji, testu $\chi^{2}$ Pearsona oraz U Manna-Whitneya. Wartość p określono na poziomie 0,05 .

\section{WYNIKI}

W badanej grupie dzieci było 197 (52,96\%) chłopców i 175 (47,04\%) dziewczynek, z czego 179 (48,12\%) badanych pochodziło ze wsi, $187(50,27 \%)$ z miasta, a $6(1,61 \%)$ było obcokrajowcami.

Dokonano podziału na 3 grupy wiekowe, biorąc pod uwagę rozwój psychomotoryczny dziecka. Najliczniejszą grupę pacjentów stanowiły dzieci w wieku 13-36 miesięcy, tj. 167 (44,89\%) badanych, następnie w grupie wiekowej 1.-12. miesiąca życia znajdowało się 118 (31,72\%) niemowląt, z kolei najmniej liczna

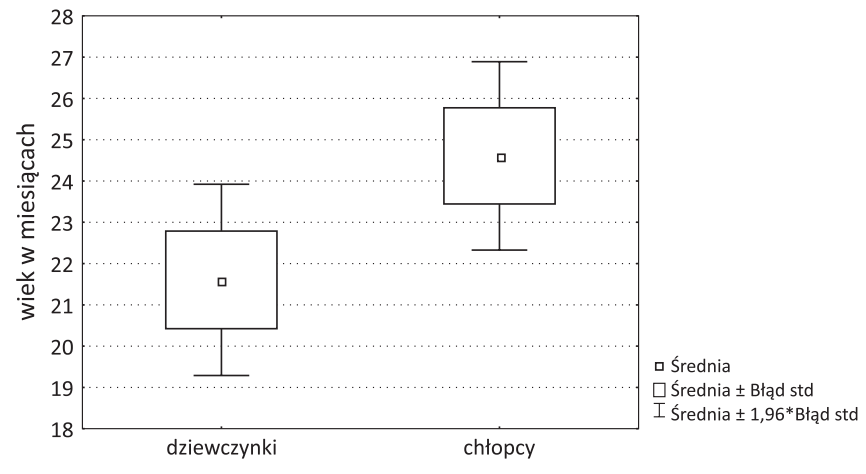

RYCINA 1. Wiek dziewczynek i chłopców z badanej grupy

grupa badanych znajdowała się w przedziale wiekowym 37-59 miesięcy, stanowiąc 87 (23,39\%) badanych.

Średnia wieku całej grupy wynosiła 23,20 $( \pm 16,06)$ miesiące, natomiast wśród dziewczynek - 21,60 $( \pm 15,63)$, a wśród chłopców - 24,61 $( \pm 16,34)$ miesięcy - rycina 1.

Najliczniejszą grupę 217 (58,33\%) pacjentów stanowiły dzieci przekazane do leczenia szpitalnego, z czego zdecydowana większość, tj. 185 (50,00\%), skierowana została na Oddział Pediatryczny, następnie 29 (13,36\%) - na Oddział Chirurgii Ogólnej dla Dzieci i po jednym dziecku na Oddział Otorynolaryngologii oraz Oddział Intensywnej Opieki Medycznej. Grupa 155 (41,67\%) badanych po zaopatrzeniu w SOR została wypisana do domu.

Najczęstszą przyczyną przyjęć na SOR były choroby układu oddechowego stanowiące blisko 30\% wszystkich przypadków oraz choroby układu pokarmowego - niespełna 20\%. Powyżej 10\% dotyczyło urazów i gorączki. Szczegółowe dane przedstawiono w tabeli 1.

Najczęstszą przyczyną skierowania dzieci z SOR na oddziały szpitalne były choroby układu oddechowego stanowiące 66 (30,41\%) przypadków, choroby układu pokarmowego - 46 $(21,20 \%)$ oraz gorączka $-38(17,51 \%)$. Pozostałe przyczyny to urazy - $13(5,99 \%)$, utrata przytomności - $11(5,07 \%)$, po 6 $(2,76 \%)$ - oparzenia i wypadki komunikacyjne. Skierowań na oddział z powodu padaczki i zadławienia było 5 (2,30\%), zatrucia - 3 (1,38\%) oraz resuscytacji - 2 (0,92\%).

W badanej grupie dzieci schorzenia układu oddechowego wymagające hospitalizacji występowały zdecydowanie częściej u chłopców niż u dziewczynek. Z powodu chorób układu pokarmowego więcej hospitalizacji dotyczyło dziewczynek, natomiast urazy dominowały u chłopców.

$\mathrm{Z}$ analizy przyczyn w odniesieniu do miejsca zamieszkania wykluczono 6 (1,61\%) przypadków obcokrajowców. Badania wykazały, iż nieco więcej dzieci pochodzących ze wsi przyjętych zostało z powodu chorób układu oddechowego w porównaniu z dziećmi pochodzącymi z miasta. Natomiast odwrotna sytuacja dotyczy hospitalizacji z powodu chorób układu pokarmowego. Pozostałe dane przedstawiono w tabeli 1.

Dokonano także podziału całej grupy badawczej na dwie kategorie, tj. grupa 1 - dzieci przyjęte na oddziały szpitalne oraz grupa 2 - dzieci wypisane z SOR. Jak wynika z analizy, w grupie przyjęć na oddziały najczęstszą przyczynę stanowiły choroby układu oddechowego, pokarmowego oraz gorączka, 
TABELA 1. Przyczyny przyjęć dzieci na Szpitalny Oddział Ratunkowy

\begin{tabular}{|c|c|c|c|c|c|}
\hline \multirow{3}{*}{ Przyczyna } & \multirow{2}{*}{ Ogółem } & \multicolumn{2}{|c|}{ Płeć } & \multicolumn{2}{|c|}{ Miejsce zamieszkania } \\
\hline & & dziewczynki & chłopcy & wieś & miasto \\
\hline & \multicolumn{5}{|c|}{$n(\%)$} \\
\hline Choroby układu pokarmowego & $70(18,82)$ & $40(22,86)$ & $30(15,23)$ & $32(17,88)$ & $37(19,79)$ \\
\hline Gorączka & $49(13,17)$ & $27(15,43)$ & $22(11,17)$ & $22(12,30)$ & $25(13,37)$ \\
\hline Urazy & $48(12,90)$ & $19(10,86)$ & $29(14,72)$ & $23(12,84)$ & $25(13,37)$ \\
\hline Wypadek komunikacyjny & $7(1,88)$ & $2(1,14)$ & $5(2,54)$ & $4(2,23)$ & $3(1,60)$ \\
\hline Oparzenia & $7(1,88)$ & $7(4,00)$ & $0(0,00)$ & $5(2,79)$ & $2(1,07)$ \\
\hline Utrata przytomności & $13(3,49)$ & $6(3,43)$ & $7(3,55)$ & $6(3,35)$ & $7(3,74)$ \\
\hline Zadławienie & $10(2,69)$ & $3(1,71)$ & $7(3,55)$ & $5(2,79)$ & $5(2,67)$ \\
\hline Zatrucia & $5(1,34)$ & $3(1,71)$ & $2(1,02)$ & $1(0,59)$ & $4(2,23)$ \\
\hline Inne & $47(12,63)$ & $23(13,42)$ & $24(12,18)$ & $19(10,61)$ & $25(13,37)$ \\
\hline Razem & $372(100 \%)$ & $175(100 \%)$ & $197(100 \%)$ & $179(100 \%)$ & $187(100 \%)$ \\
\hline
\end{tabular}
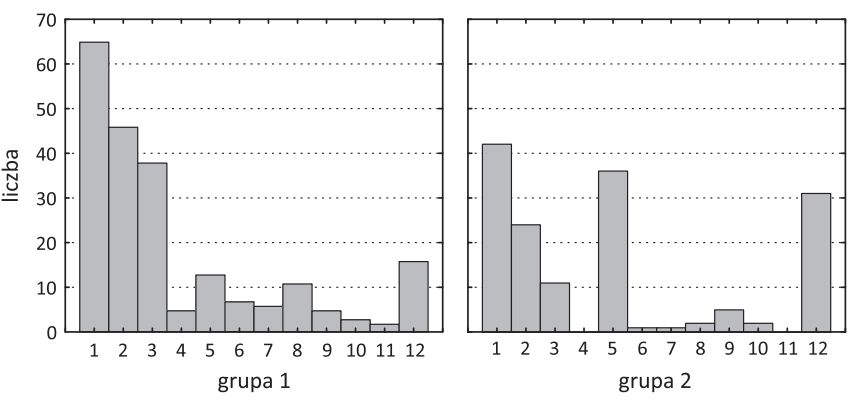

grupa 1 - dzieci przyjęte na oddziały szpitalne; grupa 2 - dzieci wypisane z SOR; 1 - choroby układu oddechowego; 2 - choroby układu pokarmowego; 3 - gorączka; 4- padaczka; 5 - urazy; 6 - wypadek komunikacyjny; 7 - oparzenia; 8 - utrata przytomności; 9 - zadławienie; 10 - zatrucia; 11 - resuscytacja; 12 - inne

RYCINA 2. Przyczyny przyjęć na Szpitalny Oddział Ratunkowy w podziale na grupy

z kolei w grupie dzieci wypisanych z SOR również przeważały choroby układu oddechowego, ale następne były urazy. Analizując zależność pomiędzy grupami a przyczyną przyjęcia na SOR, wykazano istotność statystyczną (test $\chi^{2}$ Pearsona, dokładny test Fishera; p =0,0000) - rycina 2.

W całej badanej grupie najwięcej, bo 134 (36,02\%) przyjęć było w marcu, kwietniu i maju, natomiast spadek zaobserwowano w miesiącach jesienno-zimowych. Najwięcej hospitalizacji na oddziałach szpitalnych miało miejsce w marcu, z kolei najwięcej wypisów z SOR nastąpiło w kwietniu. Nie wykazano istotnych statystycznie różnic pomiędzy ilością dzieci przyjętych na oddziały szpitalne a liczbą dzieci wypisanych z SOR w poszczególnych miesiącach (test U Manna-Whitneya; $p=0,0681$ ) - rycina 3 .

Z analizy przyjęć dzieci w obu grupach w odniesieniu do dni tygodnia wynika, że najwięcej było w soboty i niedziele (35\%). Wśród badanych najwięcej przyjęć na oddziały szpitalne było w środy i soboty, z kolei najwięcej wypisanych było w piątek i sobotę. Wykazano brak zależności statystycznej pomiędzy badanymi grupami a dniem tygodnia (test U Manna-Whitneya; $\mathrm{p}=0,6627)$ - rycina 4 .

Na podstawie wyników badań stwierdzono, że najwięcej przyjęć na oddziały szpitalne oraz dzieci wypisanych z SOR

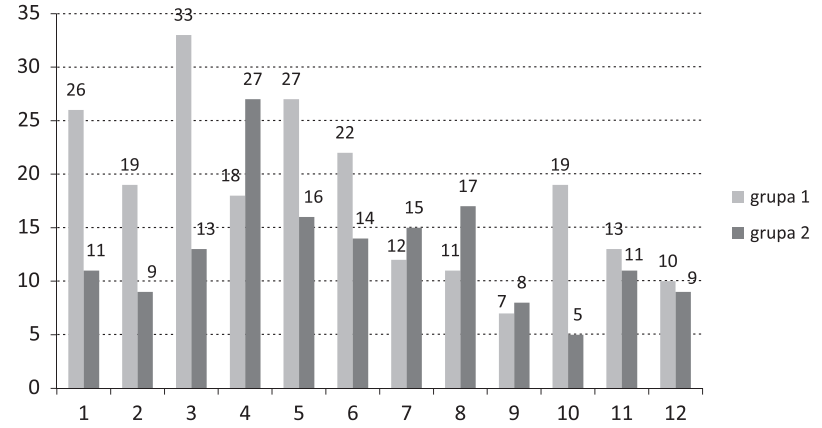

grupa 1 - dzieci przyjęte na oddziały szpitalne; grupa 2 - dzieci wypisane z SOR; 1 - styczeń; 2 - luty; 3 - marzec; 4 - kwiecień; 5 - maj; 6 - czerwiec; 7 - lipiec; 8 - sierpień; 9 - wrzesień; 10 - październik; 11 - listopad; 12 - grudzień

RYCINA 3. Liczba dzieci przyjętych w poszczególnych miesiącach roku kalendarzowego

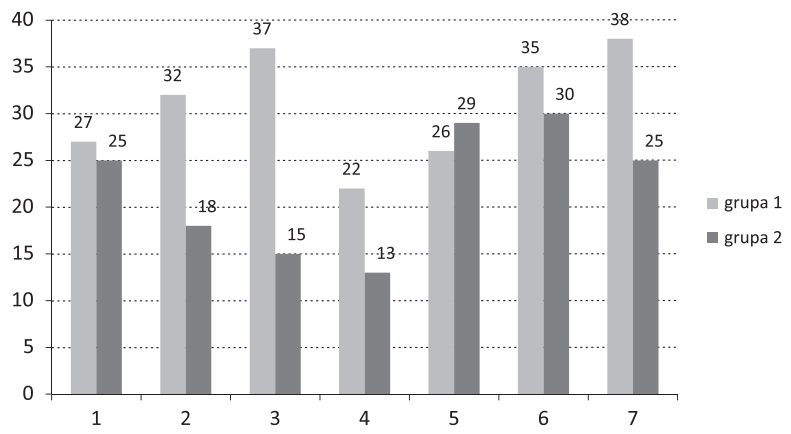

grupa 1 - dzieci przyjęte na oddziały szpitalne; grupa 2 - dzieci wypisane z SOR; 1 - poniedziałek; 2 - wtorek; 3 - środa; 4 - czwartek; 5 - piątek; 6 - sobota; 7 - niedziela

RYCINA 4. Liczba dzieci przyjęta w poszczególnych dniach tygodnia

było w godz.12.00-23.59. Porównanie obu grup wykazało brak statystycznie istotnej zależności względem cyklu dobowego (test U Manna-Whitneya; $\mathrm{p}=0,0717$ ) - rycina 5.

Wykazano brak zależności istotnej statystycznej w odniesieniu do płci $(p=0,1204)$ oraz miejsca zamieszkania $(p=0,2859$; test U Manna-Whitneya $\mathrm{p}>0,05$ ).

Średni czas pobytu dzieci na SOR liczony w minutach wynosił 77,54 (₫95,68), tj. 1 godz. i 17 min. Wśród dzieci przyjętych 


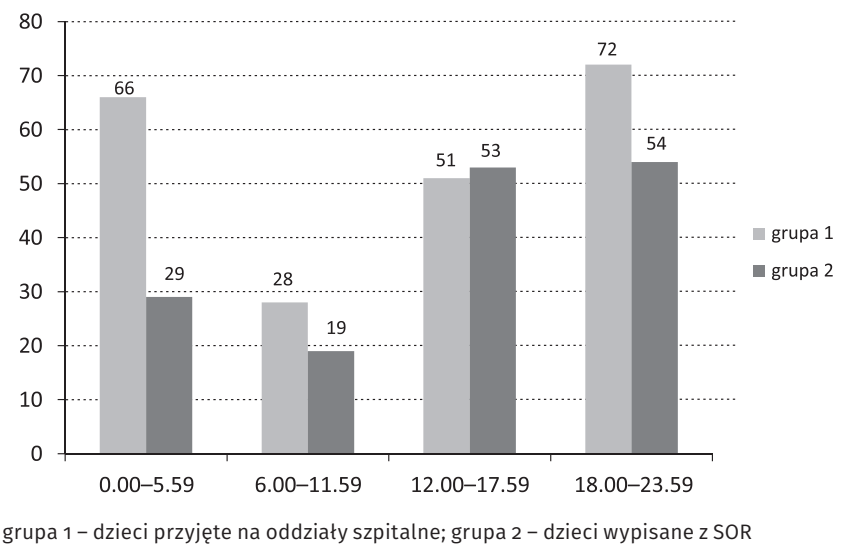

RYCINA 5. Liczba dzieci w odniesieniu do cyklu dobowego

na oddziały szpitalne średni czas pobytu na SOR wynosił 52,12 $( \pm 89,02)$ min, z kolei wśród wypisanych z SOR oscylował w granicach 113,12 (£93,58) min. Różnice średniego czasu pobytu na SOR $\mathrm{w}$ obu grupach były istotne statycznie $(\mathrm{p}=0,0000)$. Natomiast nie wykazano istotnej statystycznie zależności pomiędzy przyczyną przyjęcia na SOR a czasem trwania pobytu w SOR $(p=0,3612)$.

\section{DYSKUSJA}

Zgłaszanie się pacjentów na Szpitalny Oddział Ratunkowy z powodu nie tylko stanu zagrożenia zdrowia i życia jest problemem ogólnoświatowym [4, 5]. Celem oddziałów ratunkowych jest zapewnienie pomocy medycznej wszystkim poszkodowanym znajdującym się w stanie nagłego zagrożenia życia. W literaturze naukowej jest wiele artykułów poświęconych analizie udzielanych świadczeń w SOR [6, 7], jednakże brakuje takich analiz w odniesieniu do dzieci. Pacjent pediatryczny wymaga wnikliwej diagnostyki z uwagi na możliwość wystąpienia dość szybko postępujących objawów choroby oraz trudności w zebraniu dokładnego wywiadu.

Przeprowadzona analiza zebranych danych wykazała że w grupie dzieci do 4. r.ż. przyjętych na SOR najczęstszą przyczyną zgłoszenia były schorzenia układu oddechowego blisko 30\% wszystkich przyczyn. Badania Szarpak przeprowadzone na terenie powiatu Otwockiego dotyczyły przyczyn interwencji Zespołów Ratownictwa Medycznego u pacjentów pediatrycznych. Przytoczone badania wykazały, że do interwencji najczęściej dochodziło w okresie wiosennym, a jej przyczyną w grupie 0-4 lat były choroby układu oddechowego i urazy [2], co również potwierdzono w badaniach własnych.

Najwięcej przyjęć miało miejsce w okresie wczesnej wiosny, w soboty i niedziele oraz w godz. 12.00-24.00. W przeprowadzonych przez Szwamel i Kurpas badaniach w zakresie analizy udzielanych świadczeń na Szpitalnym Oddziale Ratunkowym w Kędzierzynie-Koźlu wykazano podobne wyniki w odniesieniu do cyklu dobowego [8].

W okresie wczesnego dzieciństwa istotnym zagrożeniem i przyczyną hospitalizacji są doznawane urazy. W badanej grupie było 48 (12,90\%) przypadków urazów, z czego o 50\% więcej przypadków było u chłopców niż u dziewczynek. Rusek i wsp. potwierdzili wykazaną zwiększoną urazowość wśród chłopców [9].
Z badań własnych wynika, iż czas pobytu na SOR wynosił 1 godz. i 17 min. W literaturze brakuje danych dotyczących średniego czasu pobytu dziecka na SOR. Dostępne dane dotyczą najczęściej wszystkich hospitalizowanych lub hospitalizowanych z wybraną jednostką chorobową, np. w badaniach Cierniak i wsp. średni czas pobytu chorych z obrażeniami klatki piersiowej wynosił 6 godz. i $21 \mathrm{~min}$ [6]. Wyniki te trudno ze sobą porównać, gdyż dotyczą zbyt zróżnicowanych grup pacjentów. Niemniej jednak należy podkreślić, iż dzieci zdecydowanie krócej oczekują na diagnostykę i ewentualną hospitalizację, co wydaje się dość oczywistym faktem.

Choroba może istotnie wpłynąć na tempo rozwoju, a nawet przyczynić się do jego zaburzenia, lecz dzięki szybkiemu rozpoznaniu i wdrożeniu odpowiedniego leczenia oraz postępowania można temu zapobiec. Dodatkowo cechą znamiennie charakterystyczną dla tej grupy wiekowej jest duża podatność na doznawanie urazów, których przyczyna w dużej mierze łączy się z psychomotorycznym rozwojem dziecka.

Pacjent pediatryczny mimo wszystko stanowi wyzwanie dla personelu medycznego tworzącego zespoły terapeutyczne, gdyż typowych, standardowych działań ratunkowych w stanach zagrożenia życia dziecka jest niewiele i w dalszym ciągu wymagają one racjonalnego opracowania potwierdzonego badaniami naukowymi, co pozwoli na wypracowanie procedur mogących uchodzić za obowiązujące. Należy bowiem kierować się świadomością, iż każdy stan pacjenta pediatrycznego przyjętego na SOR może w krótkim czasie rozwinąć się w stan zagrożenia życia dziecka. Dlatego dbałość personelu o poziom zarówno wiedzy, jak i umiejętności ma niezwykle istotny wpływ na jakość postępowania. Zatem bardzo ważna jest znajomość potencjalnych przyczyn hospitalizacji dzieci, która w połączeniu z wiedzą i kompetencjami pozwoli na swobodne i w pełni profesjonalne postępowanie z pacjentem pediatrycznym.

\section{WNIOSKI}

Najczęstszą przyczyną przyjęć dzieci na SOR w Słupsku w 2013 r. były choroby układu oddechowego. Dzieci przekazanych na oddziały szpitalne było więcej niż wypisanych do leczenia ambulatoryjnego. Najczęściej przyjęcia dzieci na SOR odbywały się w godzinach wieczornych i nocnych, w soboty i niedziele, w miesiącach wiosennych. Jak wynika z badań własnych, zarówno przyczyna przyjęcia na SOR, jak i średni czas pobytu dziecka w SOR stanowią zmienne warunkujące przyjęcie na oddział szpitalny oraz wypisanie z SOR.

\section{PIŚMIENNICTWO}

1. Falkowska E, Telusiewicz-Pacak A. Dzieci w Polsce. Dane, liczby, statystyki. Warszawa: Polski Komitet Narodowy UNICEF; 2013. p. 24-30. https:// www.unicef.pl/Co-robimy/Publikacje/Dzieci-w-Polsce (20.01.2017).

2. Szarpak Ł. Ewaluacja interwencji zespołów ratownictwa medycznego do pacjentów pediatrycznych. Nowa Pediatr 2012;3:51-4.

3. Elektroniczny podręcznik statystyki PL. Kraków: StatSoft; 2006. http:// www.statsoft.pl/textbook/stathome.html (5.10.2016). 
4. Flores-Mateo G, Violan-Fors C, Carrillo-Santisteve P, Peiró S, Argimon $\mathrm{J}-\mathrm{M}$. Effectiveness of organizational intervenions to reduce emergency department utilization: a systematic reviev. Plos One 2012;7(5):1-6. doi: 10.1371/journal.pone.0035903.

5. Tsai JC, Liang YW, Pearson WS. Utilization of emergency department in patients with non-urgent medical problems: patient preference and emergency department convenience. J Formos Med Assoc 2010;109(7):533-42. doi: 10.1016/S0929-6646(10)60088-5.

6. Cierniak M, Gardoń M, Timler D, Trendak W, Gaszyński T. Ocena czasu hospitalizacji oraz sezonowości przyjęć poszkodowanych z obrażeniami klatki piersiowej na SOR. Pol Prz Nauk Zdr 2014;4(41):269-72.
7. Lubszczyk M, Pietrus M, Sulewski M, Gajecki K, Styka L. Emerytura na SORze - analiza przyczyn hospitalizacji osób po 65 roku życia w szpitalnym oddziale ratunkowym. Geriatria 2014;8:93-101.

8. Szwamel K, Kurpas D. Analiza struktury świadczeń medycznych szpitalnego oddziału ratunkowego ze szczególnym uwzględnieniem świadczeń udzielanych pacjentom z niewielkimi urazami. Family Med Primary Care Rev 2015;17:124-30.

9. Rusek W, Pop T, Jarochowicz S, Cieplińska E, Glista J. Najczęstsze urazy kończyn górnych i dolnych u dzieci i młodzieży. Prz Med Uniw Rzesz Inst Leków 2010;4:427-34. 